\title{
Basic economic indicators of book publishing
}

\author{
Miroslav Tóth ${ }^{1 *}$, and Alena Tóthová ${ }^{2}$ \\ ${ }^{1}$ University of Economics in Bratislava, Faculty of Business Management, Department of Business \\ Economy, Dolnozemská cesta 1/b, 85235 Bratislava, Slovak Republic \\ ${ }^{2}$ University of Economics in Bratislava, Faculty of Business Management, Department of Business \\ Finance, Dolnozemská cesta 1/b, 85235 Bratislava, Slovak Republic
}

\begin{abstract}
The publishing activity and the publishing of books are part of the creative industry. A peculiarity of the book publishing industry is that it combines art, culture, business and technology. Although it creates less than $1 \%$ of job opportunities in Slovakia, it is linked to another $1 \%$ of coworkers. The importance of publishing books is also that it contributes to the employment of women and youth. In our paper we explore the book publishing industry. We find out the development of the number of enterprises, the development of the number of employees, basic economic indicators such as cash income, income, costs, profit, profitability. We follow these indicators across the book publishing industry. We examine the effectiveness of business activity by recalculating the above indicators per employee.
\end{abstract}

\section{Introduction}

Book publishers are representative of non-periodical printing. Book publishing houses are propagators of artistic, scientific and social ideas. The invention of an innovative printing in the 15th century marks the beginning of a massive spread of new ideas in Europe. Currently, the Internet is helping to spread such new mass information. The book remains popular. We see this also in the fact that in recent years we have seen a recovery in the Slovak book market accompanied by a slight increase in book sales. The general knowledge is the diversification of the reader's interest and a slight shift towards books reflecting social events. It is a gratifying news that there is a growing interest in books for children and young people. For the year 2018, a total of 11442 non-periodical titles were published, which is an increase compared to 2017. Of the total number of non-periodical titles, 9315 books and brochures are 2127 titles. The total number of copies of published publications is 15408354 pieces. As a translation from another language, 2634 nonperiodical publications were published, which is a decrease compared to 2017. The most frequent were translations from English language 1650 titles, German language 287 titles and French language 172 titles. For this reason, we want to research the basic data about book publishers.

Book publishers bring books to the reader. The book is not an ordinary commodity. The book is an instrument of education, it cultivates us, makes us better. The book, reading,

${ }^{*}$ Corresponding author: $\underline{\text { miroslav.toth } @ \text { euba.sk }}$ 
improves our creativity. Reading is the process of thinking. Reading books support our analytical and critical thinking. That's why publishers are important to our lives. Countries that develop creative industries, innovate will become leaders of the global economy.

\section{Methods}

The economics of the arts approach in which economic analysis is used to analyze the arts is the first of those established approaches. The other established approach is the art and commerce approach in which the relative position of the arts in society and in particular its relation to the commercial and industrial world is analyzed. [1] In recent years there has been increased emphasis, in both academic and political arenas, on the economic importance of the creative industries (CIs). As a result, policymakers are increasingly looking to the CIs as a source of potential growth. [2] Cultural consumption is associated with positive externalities. Those who read books, go to theatre or attend music concerts, do not only increase their own utility, but generate also positive effects for the society, for example, in the form of improved education and literacy. [3] Time spent in leisure activities, including the arts, culture and sport, can provide a range of quality of life benefits from positive effects on well-being, to self-development and social and cultural connectedness. $[4,5]$ Creativity - possibly expressed according to different patterns - can play a mediating role, explaining the local capability to exploit cultural heritage for economic purposes. $[6,7]$ The extant definition of the creative industries is based on an industrial classification that proceeds in terms of the creative nature of inputs and the intellectual property nature of outputs. [8,9]

The subject of investigation are publishers of non-periodical printing operating in the Slovak Republic. They are practically publishers that publish book publications and brochures. The time period is 2015 to 2018 .

The first aim of the research is to find out the development of the number of publishers on the book market in the Slovak Republic. In the reference year we do research:

- the number of active publishing houses,

- the number of publishers that did not or did not interrupt publishing, and

- the number of publishing houses that have ceased their activities.

The second aim is to research the basic economic indicators (for the year concerned): income, revenue, costs, profit or loss, profitability of costs.

The third aim is to convert basic economic indicators per employee.

From the results of the calculations we want to find out the development of the above mentioned indicators, to look for the cause of positive or negative development.

Publishing companies belong, by size, to the group of small and medium-sized enterprises.

The area under study is, according to the statistical classification of economic activities (SK NACE Rev. 2), class 58.11.0 Book publishing, non-periodical publications. This class includes the publishing of books in printed, electronic (CD, electronic display, etc.) or audio form or on the Internet. This class includes e.g. publishing of books, brochures, leaflets and similar publications, including publishing dictionaries and encyclopaedias, publishing atlases, maps and graphic works, all in physically printed form. These also include the publication of non-periodical publications on CD-ROM, such as the publication of sound recordings of books, publishing encyclopedias, etc. [10,11, 12]

The subject of the statistical survey is the publication of non-periodical publications (mainly printed publications in book form), which were through statistical survey through the National Educational Center. The Ministry of Culture of the Slovak Republic pursuant to Act No. 540/2001 Coll. on State Statistics, as amended, carries out long-term state 
statistical surveys in the field of culture every year. Statistical reporting units for nonperiodical publications are publishers operating on the Slovak market, but also state institutions, municipalities, non-governmental organizations and individuals who issued non-periodical publications in the relevant year applied for an International Standard Book Number (ISBN) agency in the Slovak Republic and it is the Slovak National Library. Since 2015, two economic modules have been included in the statistical survey. In these modules, we find out basic information on incomes and expenditures of reporting agents, as well as information on employment and persons who provide the given cultural area. Since 2016, the number of employees has been calculated as the average registered number of employees. $[13,14]$

A non-periodical publication is a special-purpose printed matter, a reproduction of a literary, photographic, scientific or artistic work, usually issued as a one-off publication, even in parts, irrespective of the form and method of processing, publication or production. The largest group of non-periodical publications are books and brochures.

A publisher of a non-periodical publication is a legal entity or a natural person who fulfills the conditions under special regulations (Commercial Code, Trade Licensing Act) and has paid the costs for their publication or production. A publisher or editor or publisher is an institution or individual who has the intellectual responsibility for publishing a publication. Sometimes a distinction is made between publisher and publisher. The publisher prepares and finances the publication, but the actual publication is carried out by the publisher. The difference is that in the case of publishing the work through the publishing house usually does not bear any cost of publishing the author, but the entire investment is on the shoulders of the publisher (editing, proofreading, graphics, wrapping, printing, distribution, marketing and other activities). The remuneration for the author is usually a share of the profits from the work as agreed with the publisher. Author is the individual who created the work. The author and creator of a work of art that is the result of the author's own creative intellectual activity. According to the law, the author is the owner and has the right to his work which arises at the moment when it is expressed in a form perceptible by the senses, regardless of its form, content, quality, purpose or form of expression. In summary: the publisher is the publisher; the publisher is the institution involved in the publication of books or other documents.

\section{Results and Discussions}

The first task of the research is to develop the number of non-periodical print publishers. Overall, the number of enterprises increased in the period under review. The highest increase was in 2018, when the number of enterprises increased by 296 business units compared to the previous year. At the same time, we can see that the number of active enterprises increased by 223 business units compared to last year. Despite the fact that the period of 2017 and 2018 was favourable for publishing years (growth of sales), its business was suspended or interrupted year-on-year by up to 68 business units. Five businesses have ended their business. The reason for this is that in 2016 and 2017, businesses in this sector suffered a loss of 22 and 15 mil. $€$.

In the sample of 2018 , there were a total of 1,969 enterprises. Of this number, $84.26 \%$ were in active business, $14.68 \%$ were not publishing or had discontinued activities. $1.07 \%$ ended publishing activities. We compared these data with a four-year average. We found out that even in this period the shares of individual indicators are practically the same.

The development of the number of publishing houses was mainly influenced by the economic results during the period under review. Income decreased by 23 mil. $€$. In 2017 there was an increase in income from sales of books, but still lagged behind Income from 2015 by 2 million. $€$. Until 2018 was extraordinarily successful, sales increased by $24 \%$ compared to the previous year, the increase in Income 22 mil. $€$. The revenue indicator developed positively. 
Table 1. Number of publishers providing non - periodical publications (book publishing).

\begin{tabular}{|l|r|r|r|r|r|r|r|c|}
\hline Indicator / Year & 2014 & 2015 & 2016 & 2017 & 2018 & 2018 & Average & Share \\
\hline Number of enterprises & 1635 & 1660 & 1673 & 1673 & 1969 & $100,00 \%$ & 1722 & $100,00 \%$ \\
\hline $\begin{array}{l}\text { Year - on - year } \\
\text { change }\end{array}$ & -- & 25 & 13 & 0 & 296 & -- & -- & -- \\
\hline $\begin{array}{l}\text { Actively pursued } \\
\text { publishing activities }\end{array}$ & 1392 & 1393 & 1417 & 1436 & 1659 & $84,26 \%$ & 1459 & $84,75 \%$ \\
\hline $\begin{array}{l}\text { Year - on - year } \\
\text { change }\end{array}$ & -- & 1 & 24 & 19 & 223 & -- & -- & -- \\
\hline $\begin{array}{l}\text { Did not/ interrupt } \\
\text { publishing activities }\end{array}$ & 230 & 246 & 244 & 221 & 289 & $14,68 \%$ & 246 & $14,29 \%$ \\
\hline $\begin{array}{l}\text { Year - on - year } \\
\text { change }\end{array}$ & -- & 16 & -2 & -23 & 68 & -- & -- & -- \\
\hline Ended publishing & 13 & 21 & 17 & 16 & 21 & $1,07 \%$ & 18 & $1,02 \%$ \\
\hline $\begin{array}{l}\text { Year - on - year } \\
\text { change }\end{array}$ & -- & 8 & -4 & -1 & 5 & -- & -- & -- \\
\hline
\end{tabular}

Source: own calculations according to KULT 4-01 Ročný výkaz o neperiodických publikáciách 2014, 2015, 2016, 2017, 2018.

Compared to 2015 , it increased by 2422 mil. $€$, no increase by $50.28 \%$. Growth rate in 2018 was $18.68 \%$, but the absolute increase revenue was 23.622 million. $€$. The period of 2017 and 2018 was favourable for book publishers, as the positive effects of previous years were reflected. This effect was an increase in book sales. In 2015, 5,640,646 copies were sold, in 2016 it was almost one million more. Adverse developments occurred in 2017, with only $5,449,383$ book copies sold. The following year was favourable, sales increased by $35.68 \%$, meaning that 7,393,201 books were sold in 2018 .

Table 2. Basic economic indicators - book publishing.

\begin{tabular}{|l|c|c|c|c|c|}
\hline Indicator / Year & 2015 & 2016 & 2017 & 2018 & $\begin{array}{c}\text { Index } \\
2018 / 2015\end{array}$ \\
\hline Income $(€)$ & 93499164 & 70903767 & 91710354 & 113718735 & -- \\
\hline Index $\mathrm{R}_{\mathrm{n}} / \mathrm{R}_{\mathrm{n}-1}$ & 1,0000 & 0,7583 & 1,2934 & 1,2400 & 1,2163 \\
\hline Revenue $(€)$ & 48463041 & 49216652 & 72830651 & 86432949 & -- \\
\hline Index $\mathrm{R}_{\mathrm{n}} / \mathrm{R}_{\mathrm{n}-1}$ & 1,0000 & 1,0156 & 1,4798 & 1,1868 & 1,7835 \\
\hline Cost $(€)$ & 70838987 & 63842667 & 58164644 & 74349683 & -- \\
\hline Index $\mathrm{R}_{\mathrm{n}} / \mathrm{R}_{\mathrm{n}-1}$ & 1,0000 & 0,9012 & 0,9111 & 1,2783 & 1,0496 \\
\hline Profit, Loss $(€)$ & -22375946 & -14626015 & 14666007 & 12083266 & -- \\
\hline Index $\mathrm{R}_{\mathrm{n}} / \mathrm{R}_{\mathrm{n}-1}$ & 1,0000 & 0,6536 & $-1,0027$ & 0,8239 & $-0,5400$ \\
\hline Year - on - year change $(€)$ & -- & 7749931 & 29292022 & -2582741 & -- \\
\hline Profitability of costs & $-31,59 \%$ & $-22,91 \%$ & $25,21 \%$ & $16,25 \%$ & - \\
\hline
\end{tabular}

Source: own calculations according to KULT 4-01 Ročný výkaz o neperiodických publikáciách 2015, 2016, 2017, 2018.

Based on the above data, we have quantified the industry's profit and cost-effectiveness. The years 2015 and 2017 are loss-making and the profitability of the industry is also negative. The big reversal occurs only in 2017 , the year-on-year change in profit increased 
by 29 mil. $€$. This also means cost-effectiveness of $25.21 \%$. In 2015 and 2016, a loss of 39 mil. $€$. Despite the favourable years 2017 and 2018, profit total 26.7 mil. $€$, the deficit is still almost 13 mil. $€$.

In the next part of the thesis we focus on economic indicators calculated per employee. An employee is a full-time or part-time employee. The number of employees was calculated as the average registered number of employees. In the monitored years we can see that the number of employees increased. In 2016 it was a 13\% increase, a year later a $10 \%$ increase. In 2014, there was an absolute increase of 501 employees, an increase of $22 \%$ over the previous year, but a year-on-year increase of $53 \%$. Income per employee in 2015 was at a high level, $52205 €$. By the following year, the number of employees increased by 235 persons, but at the same time the income per employee indicator decreased by $€ 17,208$. In the following years the number of employees increased. This had a negative impact on the indicator of income per employee, as in the next two years it reached only $80 \%$ of the level of 2015 . Similarly, the indicator of income per employee developed similarly. However, this indicator increased by approximately 30\% in 20172018 compared to the previous period. It increased by $16.7 \%$ over the four-year period. This increase was despite the almost $53 \%$ increase in the number of workers. Significantly to the improvement of the indicator was helped by the fact that revenue in five years increased by up to $78 \%$. The cost development of one employee has generally been favourable. Over the four years it has fallen by almost 12,000 euros, a relative decrease of $31 \%$.

Table 3 Basic economic indicators per employee - book publishing.

\begin{tabular}{|c|c|c|c|c|c|}
\hline Indicator / Year & 2015 & 2016 & 2017 & 2018 & $\begin{array}{c}\text { Index } \\
2018 / 2015\end{array}$ \\
\hline Employees & 1791 & 2026 & 2236 & 2737 & -- \\
\hline Index $R_{n} / R_{n-1}$ & 1,0000 & 1,1312 & 1,1037 & 1,2241 & 1,5282 \\
\hline Year - on - year change (p.) & -- & 235 & 210 & 501 & -- \\
\hline Income $(€)$ / Employee & 52205 & 34997 & 41015 & 41549 & -- \\
\hline Index $R_{n} / R_{n-1}$ & 1,0000 & 0,6704 & 1,1720 & 1,0130 & 0,7959 \\
\hline Year - on - year change $(€)$ & -- & -17208 & 6018 & 533 & -- \\
\hline Revenue $(€)$ / Employee & 27059 & 24293 & 32572 & 31579 & \\
\hline Index $\mathrm{R}_{\mathrm{n}} / \mathrm{R}_{\mathrm{n}-1}$ & 1,0000 & 0,8978 & 1,3408 & 0,9695 & 1,1670 \\
\hline Year - on - year change $(€)$ & -- & -2767 & 8279 & -992 & -- \\
\hline Cost $(€)$ / Employee & 39553 & 31512 & 26013 & 27165 & \\
\hline Index $R_{n} / R_{n-1}$ & 1,0000 & 0,7967 & 0,8255 & 1,0443 & 0,6868 \\
\hline Year - on - year change $(€)$ & -- & -8041 & -5499 & 1152 & -- \\
\hline Profit, Loss (€) / Employee & -12494 & -7219 & 6559 & 4415 & -- \\
\hline Index $R_{n} / R_{n-1}$ & 1,0000 & 0,5778 & $-0,9086$ & 0,6731 & $-0,3534$ \\
\hline Year - on - year change $(€)$ & -- & 5274 & 13778 & -2144 & -- \\
\hline $\begin{array}{l}\text { Profitability of costs / } \\
\text { Employee }\end{array}$ & $-31,59 \%$ & $-22,91 \%$ & $25,21 \%$ & $16,25 \%$ & -- \\
\hline
\end{tabular}

Source: own calculations according to KULT 4-01 Ročný výkaz o neperiodických publikáciách 2015, 2016, 2017, 2018.

The development of the level of profit per employee copies the development of total profit. In 2015 and 2016, an average loss of 12 resp. 7 thousand euro per employee. This 
also means that the profitability of costs per employee was negative (-31.59\% in 2015 and $22.91 \%$ in 2016).

The economic results of the publisher of non-periodical printing (books) are influenced mainly by purchasing demand (sufficient free household money for cultural products). The demand for books is dependent on the business cycle and changes in the prices of goods and services. An important factor is the offer of bestsellers for different age groups of the population, the offer of popular educational publications. The demand for books is also influenced by social networks, film and television production. The book remains aesthetic goods, collectors' items and social links.

\section{Acknowledgement}

This paper is the partial result of the scientific grants

VEGA n. 1/0340/19 "The Entrepreneurial Dimension of Creative industries in the Context of Innovation and Smart Growth" (share $50 \%$ ) and

VEGA n. 1/0240/20 „Financial Aspects of Sustainable Business - Enterprise Succession Solution for Small and Medium-sized Enterprises“ (share 50\%).

\section{References}

1. E. Dekker, Two approaches to study the value of art and culture, and the emergence of a third. Journal of Cultural Economics 39, 309-326 (2015) https://doi.org/10.1007/s10824-014-9237-y

2. M. S. Sigurdardottir, M. Candi, Growth strategies in creative industries. Creativity and Innovation Management 28, 4, 421-575 (2019) https://doi.org/10.1111/caim.12334

3. K. J. Borowiecki, T. Navarrete, Fiscal and economic aspects of book consumption in the European Union. Journal of Cultural Economics 42, 309-339 (2018) https://doi.org/10.1007/s10824-017-9307-z

4. D. Wheatley, C. Bickerton, Measuring changes in subjective well-being from engagement in the arts, culture and sport. Journal of Cultural Economics 43, 421-442 (2019). https://doi.org/10.1007/s10824-019-09342-7

5. D. Wheatley, C. Bickerton, Subjective well-being and engagement in arts, culture and sport. Journal of Cultural Economics 41, 23-45 (2017) https://doi.org/10.1007/s10824-016-9270-0

6. S. Cerisola, Creativity and local economic development: The role of synergy among different talents. Papers in Regional Science 97, 2, 199 - 209 (2018)

7. S. Cerisola, A new perspective on the cultural heritage-development nexus: the role of creativity. Journal of Cultural Economics 43, 21-56 (2019) https://doi.org/10.1007/s10824-018-9328-2

8. E. Munro, Building soft skills in the creative economy: Creative intermediaries, business support and the 'soft skills gap". Poetics 64, 14-25 (2017) https://doi.org/10.1016/j.poetic.2017.07.002

9. J. Potts, S. Cunningham, J. Hartley, et al., Social network markets: a new definition of the creative industries. Journal of Cultural Economics 32, 167-185 (2008) https://doi.org/10.1007/s10824-008-9066-y

10. www.financnasprava.sk/_img/pfsedit/Dokumenty_PFS/Podnikatelia/Clo_obchodny_to var/EORI/StatistickaKlasifikaciaEkonomickychCinnosti.pdf [accessed 27.3.2020]

11. Zákon č. $289 / 2013$ o povinných výtlačkoch periodických publikácií, neperiodických publikácií a rozmnoženín audiovizuálnych diel

12. Zákon č. 185/2015 autorský zákon 
13. Národné osvetové centrum (2019).Správa o štátnom štatistickom zist'ovaní v oblasti kultúry 2018. Bratislava, NOC Oddelenie vzdelávania, výskumu a štatistiky december 2019. http://www.culture.gov.sk/ministerstvo/statistika-kultury-1a8.html [accessed 27.3.2020]

14. KULT 4-01 Ročný výkaz o neperiodických publikáciách. http://www.culture.gov.sk /ministerstvo/statistika-kultury-1a8.html [accessed 27.3.2020] 